\title{
An Empirical Study on Employees Job Satisfaction towards a Private Limited Company at Salem
}

\author{
${ }^{1}$ R. Shenbagam, ${ }^{2}$ Dr.S.Sekar \\ ${ }^{1}$ Assistant professor / Salem Christian College of Arts and Science, Salem. \\ ${ }^{2}$ Asst. Professor, Department of Business Administration, Aovt. Art'
}

\begin{abstract}
Human Resource Management is a term used to refer philosophy, policies, procedures and practices related to the management of people begin an organization. Today every organization has to face highly competition. Therefore organization tries to do right thing at the right time. In that situation HRM plays major role to achieve organizational goals. Satisfaction is the one of the major concept in HRM. Employee satisfaction is a measure of how happy workers are with their job and working environment. Keeping morale high among workers can be of tremendous benefit to any company, as happy workers will be more likely to produce more take fewer days off, and stay loyal to the company. There are many factors in improving satisfaction. This is a descriptive study. Data was collected from 50 respondents.

Objectives of the study

* To evaluate the factors influencing job satisfaction of the employees in the study unit.

* To find out the employees job satisfaction toward monetary and non-monetary benefits offered by the private company at Salem

* To examine the relation between the levels of satisfaction and employees' demographic factors.

* To identify the employees satisfaction with regard to welfare facilities provided by the concern.

Keywords: Job satisfaction, Demographic factors, Morale, Monetary and Non-Monetary benefits.
\end{abstract}

\section{Introduction}

Job satisfaction is an attitude which results from balancing and summation of many specific likes and dislikes experienced in connection with the job- their evaluation may rest largely upon one's success or failure in the achievements of personal objective and upon perceived combination of the job and combination towards the ends.

According to Pestonejee, "Job satisfaction can be taken as a summation of employee's feelings in four important areas". They are:

- Job-nature of work (dull, dangerous, interesting), hours of work, fellow workers, opportunities on the job for promotions and advancement (prospects), overtime regulations, interest in work, physical environment, and machines \& tools.

- Management- supervisory treatment, participation, rewards and punishments, praises and blames, leaves policy and favoritism.

- Social relations- friends and associates, neighbors, attitudes towards people in community, participation in social activity scalability and caste barrier.

- Personal adjustment-health and emotionality.

\section{Importance Of Job Satisfaction}

$>$ Job satisfaction is an important indicator of how employees feel about their job and a predicator of work behavior such as Organizational, Citizenship, Absenteeism, and Turn over.

$>$ Job satisfaction can partially mediate the relationship of personality variables and deviant work behavior.

$>$ Common research findings is that job satisfaction is correlated with life style.

This correlation is reciprocal meaning the people who are satisfied with the life tends to be satisfied with their jobs and the people who are satisfied their jobs tends to satisfied with their life.

$>$ This is vital piece of information that is job satisfaction and job performance is directly related to one another. Thus it can be said that, "A happy worker is a productive worker."

$>$ It gives clear evidence that dissatisfied employees skip work more often and more like to resign and satisfied worker likely to work longer with the organization.

\section{Need Of The Study}

The study is done for measuring the level of job satisfaction of the employees in a pvt., ltd., company a Salem. This study is carried out to find out the level off job satisfaction among the employees. This is helped to 
private company owners to know about employees feelings. This is essentially much needed to know the employee views and to job opinion related to job and other related aspects.

\section{Scope Of The Study}

The study helps in improving the working condition of the organization and knowing the employee relationship with the top management, the superior and the co-concern. Also helps in ascertaining the satisfaction towards monetary and non-monetary compensation given to them. The scope of the study includes the measurement of the satisfactory level of the employees regarding the welfare measurement.

\section{Objectives Of The Study}

* To evaluate the factors influencing job satisfaction of the employees in the study unit.

* To find out the employees job satisfaction toward monetary and non-monetary benefits offered by the company.

* To examine the relation between the level of satisfaction and employees' demographic factor.

* To identify the employees satisfaction with regard to welfare facilities provided by the concern.

\section{Review Of Literature}

HOP POCK (1934): Hop pock's study indicated that job satisfaction index varied with profession again. In the year 1952 Robinson and Hop pock found that untrained and unskilled worker get minimum satisfaction while persons encaged in skilled.

VROOM (1964): Vroom has suggested that following five dimensions of job satisfaction after surveying several studies.

1. Attitude towards organization and management.

2. Attitude towards job content

3. Attitude towards supervision

4. Attitude towards working conditions

5. Attitude towards co-worker.

CHALLET WRIGHT AND TASKS (1962): Chalet studies the status of job satisfaction in the work place and founded that between 70 and $80 \%$ off workers reported that they are satisfied with their employees.

IV. Data Analysis And Interpretation

Table-1 Demographic Profile Of The Respondents

\begin{tabular}{|c|c|c|c|}
\hline S.NO & CATEGORY & PARTICULARS & PERCENTAGE \\
\hline \multirow[b]{2}{*}{1.} & \multirow[b]{2}{*}{ Gender } & Male & $66 \%$ \\
\hline & & Female & $34 \%$ \\
\hline \multirow{3}{*}{2.} & \multirow{3}{*}{ Marital status } & Married & $30 \%$ \\
\hline & & Unmarried & $68 \%$ \\
\hline & & Divorced & $2 \%$ \\
\hline \multirow{4}{*}{3.} & \multirow{4}{*}{ Age group } & $18-20$ & $18 \%$ \\
\hline & & $21-25$ & $42 \%$ \\
\hline & & $26-30$ & $32 \%$ \\
\hline & & 31-above & $8 \%$ \\
\hline \multirow{5}{*}{4.} & \multirow{5}{*}{ Department } & Human Resources & $10 \%$ \\
\hline & & Marketing & $14 \%$ \\
\hline & & Finance & $10 \%$ \\
\hline & & SAP & $32 \%$ \\
\hline & & Web development & $34 \%$ \\
\hline \multirow{4}{*}{5.} & \multirow{4}{*}{ Monthly income } & Below 5000 & $14 \%$ \\
\hline & & $5000-10000$ & $38 \%$ \\
\hline & & $10000-20000$ & $28 \%$ \\
\hline & & 20000\& above & $20 \%$ \\
\hline \multirow{3}{*}{6.} & \multirow{3}{*}{ Educational qualification } & UG degree & $60 \%$ \\
\hline & & PG degree & $36 \%$ \\
\hline & & M-phil \&Ph.D. & $4 \%$ \\
\hline \multirow{4}{*}{7.} & \multirow{4}{*}{ Experience } & $0-1$ year & $26 \%$ \\
\hline & & $2-3$ years & $40 \%$ \\
\hline & & 4-6 years & $20 \%$ \\
\hline & & Above 7years & $14 \%$ \\
\hline \multirow{4}{*}{8.} & \multirow{4}{*}{$\begin{array}{l}\text { Employees traveling } \\
\text { distance from house to } \\
\text { office }\end{array}$} & $0-1 \mathrm{~km}$ & $28 \%$ \\
\hline & & $2-5 \mathrm{~km}$ & $36 \%$ \\
\hline & & $6-8 \mathrm{~km}$ & $20 \%$ \\
\hline & & 9-above & $16 \%$ \\
\hline
\end{tabular}

Source: primary data 
$66 \%$ of the respondent are male. $68 \%$ are un married. $42 \%$ are come under the category of $21-25.34 \%$ of the respondents are web development department. $38 \%$ of the respondents monthly income is $5000-10000.60 \%$ the respondents are under graduates. $40 \%$ of the respondents having $2-3$ years experiences. $36 \%$ of the respondents are having their office in nearby $2-5 \mathrm{~km}$.

Table-2Employee opinion about job satisfaction

\begin{tabular}{|c|c|c|c|c|}
\hline S.NO & PARTICULARS & $\begin{array}{l}\text { HIGHLY } \\
\text { SATISFIED }\end{array}$ & SATISFIED & DISSATISFIED \\
\hline 1. & Opinion about job satisfaction & $48 \%$ & $36 \%$ & $16 \%$ \\
\hline 2. & $\begin{array}{l}\text { Employees relationship } \\
\text { management }\end{array}$ & $54 \%$ & $42 \%$ & $4 \%$ \\
\hline 3. & Satisfaction level on office timing & $56 \%$ & $32 \%$ & $12 \%$ \\
\hline 4. & $\begin{array}{l}\text { Relationship with the } \\
\text { co-consultant }\end{array}$ & $52 \%$ & $42 \%$ & $6 \%$ \\
\hline 5. & $\begin{array}{l}\text { Employees feeling with revision of } \\
\text { salary }\end{array}$ & $42 \%$ & $44 \%$ & $14 \%$ \\
\hline 6. & $\begin{array}{l}\text { Satisfaction level of policy rules \& } \\
\text { regulation }\end{array}$ & $50 \%$ & $44 \%$ & $6 \%$ \\
\hline
\end{tabular}

\section{Source: primary data}

$48 \%$ of the respondents are highly satisfied in their job. $54 \%$ of the employees are highly satisfied with their management relation. $56 \%$ are highly satisfied with office timing. $44 \%$ are satisfied their salary. $50 \%$ highly satisfied with their rules and regulation of the company policy.

Table-3 Satisfaction level of the respondents

\begin{tabular}{|l|l|l|l|l|}
\hline S.NO & PARTICULARS & VERY GOOD & GOOD & BAD \\
\hline 1. & Working environment & $76 \%$ & $22 \%$ & $2 \%$ \\
\hline 2. & Motivation method & $66 \%$ & $26 \%$ & $8 \%$ \\
\hline 3. & Promotional activity & $30 \%$ & $38 \%$ & $32 \%$ \\
\hline 4. & T raining program & $60 \%$ & $36 \%$ & $4 \%$ \\
\hline
\end{tabular}

Source: primary data

$76 \%$ of the respondents are sated that, working environment is very good.66\% are motivated in their job. $38 \%$ of the respondents are sated that, company promotion activity are good in the company. $60 \%$ are satisfies their training progaramme,

\begin{tabular}{|l|l|l|l|}
\hline \multicolumn{4}{|l|}{ TABLE-4 } \\
\hline S.NO & PARTICULARS & YES & NO \\
\hline $\mathbf{1}$ & Increment relating to job performance & $80 \%$ & $20 \%$ \\
\hline $\mathbf{2 .}$ & Satisfaction forwards training & $84 \%$ & $16 \%$ \\
\hline $\mathbf{4 .}$ & $\begin{array}{l}\text { Employees working as per educational } \\
\text { qualification }\end{array}$ & $78 \%$ & $22 \%$ \\
\hline $\mathbf{5 .}$ & $\begin{array}{l}\text { Monthly meetings for employees } \\
\text { queries }\end{array}$ & $100 \%$ & $0 \%$ \\
\hline
\end{tabular}

\section{Source: primary data}

$80 \%$ of the respondents have given the opinion on increment, $84 \%$ have stated that forward training are undertaken by the company. 100 of the respondents are stated that, conducting monthly meeting for employee queries and $96 \%$ arrange tours for employee for reliving there stress.

\section{Testing Of Hypotheses}

To find out the relationship between age and job satisfaction

\section{Null Hypothesis}

There is no relationship between age of the respondents and job satisfaction

\section{Alternative Hypothesis}

There is a relation between age of the respondents and job satisfaction.

\section{Calculation}

\begin{tabular}{|l|l|l|l|l|}
\hline \multirow{2}{*}{ Age } & Levels of satisfaction on job & \multirow{2}{*}{ Total } \\
\cline { 2 - 5 } & Highly satisfied & satisfied & dissatisfied & \\
\hline $18-20$ & 4 & 6 & 1 & 11 \\
\hline $21-25$ & 5 & 5 & 2 & 12 \\
\hline $26-30$ & 4 & 7 & 2 & 13 \\
\hline Above 30 & 3 & 8 & 3 & 14 \\
\hline Total & 16 & 26 & 8 & 50 \\
\hline
\end{tabular}

Formula $=\mathbf{x}^{2}=\sum(\mathbf{0 i - E i})^{2} / \mathbf{E}$ 


\begin{tabular}{|l|l|l|l|l|}
\hline $\begin{array}{l}\text { Observed } \\
\text { frequency(Oi) }\end{array}$ & Expected frequency(Ei) & Oi-Ei & $(\text { Oi-Ei })^{2}$ & $(\text { Oi-Ei })^{2} / \mathbf{E}$ \\
\hline 4 & 3.52 & 0.48 & 0.23 & 0.068 \\
\hline 6 & 5.72 & 0.28 & 0.07 & 0.012 \\
\hline 1 & 1.76 & -0.76 & 0.58 & 0.329 \\
\hline 5 & 3.84 & 1.16 & 1.34 & 0.348 \\
\hline 5 & 6.24 & -1.24 & 1.53 & 0.245 \\
\hline 2 & 1.92 & 0.08 & 6.40 & 3.333 \\
\hline 4 & 4.16 & -0.16 & .02 & 4.807 \\
\hline 7 & 6.76 & 0.24 & .05 & 7.396 \\
\hline 2 & 2.08 & -0.08 & 2.50 & 1.201 \\
\hline 3 & 4.48 & -1.48 & 1.29 & 0.287 \\
\hline 8 & 7.28 & 0.72 & 0.51 & 0.070 \\
\hline 3 & 224 & 0.76 & 0.57 & 0.254 \\
\hline Total & & & & 18.37 \\
\hline
\end{tabular}

\section{Calculation}

Degree of freedom $=(c-1)(r-1)$

$$
\begin{aligned}
& =(3-1)(4-1) \\
= & 2 \times 3=6
\end{aligned}
$$

Tabulated value $=\mathbf{2 3 . 5 8}$

Calculated value $=18.37$

Since the calculated value is $<$ table value the null hypothesis is accepted.

Inference

Here the calculated values less than tabulated value so null hypothesis is accepted. Therefore there is no significant relationship between employees and job satisfaction.

\section{Suggestions}

* It is suggested to provide effective training to the employee working in the organization.

* Most of the employees suggested that organization should motivate the employees.

* Merits and good performance should always be encouraged by way of appreciation letters, rewards, promotion, and special increments.

* The management the company should provide opportunity to the employees to share their valuable views and suggestions.

\section{Conclusion}

Employee's job satisfaction is the part of feeling of employees after performing task. The feeling of employees after performing a task. The feeling would be a positive or negative depending upon whether needs is satisfied or not. So the employee's job satisfaction is very important for every organization. This study has helped to know about the employee's job satisfaction in pvt ltd. I can conclude that the employees of the pvt., ltd are satisfied with their jobs and overall environment of the organization. Research clearly shows that origination provides jobs satisfaction.

\footnotetext{
[1]. Human resource management- Aswathappa

[2]. Human resource management- 1.m.prasad

[3]. HRM Review

[4]. HRD Times

[5]. www.workfore.com
}

\section{References}

